\title{
An emendation of Phallus glutinolens
}

\author{
Larissa Trierveiler-Pereira • Clarice Loguercio-Leite • \\ Francisco D. Calonge $\cdot$ Iuri G. Baseia
}

Received: 5 February 2009/Revised: 30 April 2009/Accepted: 7 May 2009/Published online: 29 May 2009

(C) German Mycological Society and Springer 2009

\begin{abstract}
Phallus glutinolens was described from Brazil by Möller in 1895. A new collection of P. glutinolens from the Brazilian Atlantic Forest revealed that Möller's original description was based on young specimens. New information on morphology is provided for P. glutinolens, and an emendation of the species circumscription is presented. This article also presents a key to differentiate the known Brazilian members of the genus Phallus.
\end{abstract}

\section{Introduction}

In 1895, Möller published a mycological gem on the phalloid fungi of Brazil. Four new genera were described: Protubera, Blumenavia, Aporophallus and Itajahya, as well

L. Trierveiler-Pereira $(\bowtie) \cdot$ C. Loguercio-Leite

Depto. Botânica, Universidade Federal de Santa Catarina,

Campus Universitário,

CEP 88040-900, Florianópolis, SC, Brazil

e-mail: 1t_pereira@yahoo.com.br

C. Loguercio-Leite

e-mail: clleite@ccb.ufsc.br

F. D. Calonge

Real Jardín Botánico, CSIC,

Plaza de Murillo 2,

28014, Madrid, Spain

e-mail: calonge@rjb.csic.es

I. G. Baseia

Depto. Botânica, Ecologia e Zoologia,

Universidade Federal do Rio Grande do Norte,

Campus Universitário,

CEP 59072-970, Natal, RN, Brazil

e-mail: baseia@pesquisador.cnpq.br as eight new species: Protubera maracuja, Clathrus chrysomycelinus, Colus garciae, Blumenavia rhacodes, Aporophallus subtilis, Itajahya galericulata, Ithyphallus glutinolens and Dictyophora callichroa.

Möller's most important fungal collections, including Brazilian specimens, were housed in the Botanical Museum Berlin-Dahlem (B), which, unfortunately, was destroyed during World War II (Fidalgo 1968). Hiepko (1987) asserted that all the material of Uredinales and imperfect fungi was saved, while the remainder of the herbarium of fungi was destroyed. However, some of Möller's collections are still kept in the Herbarium Biozentrum Klein-Flottbek (HBG), specially preserved in alcohol (Friederichsen 1977).

The genus Phallus is represented by a varying number of species, depending on the author. Thus, whereas Kreisel (1996) accepts 33 species, Calonge (2005) recognizes only 25. If we include the taxa proposed during the last 3 years: Phallus formosanus ( $\mathrm{Li}$ et al. 2005), P. maderensis (Calonge et al. 2008), P. luteus (Kasuya 2008), and $P$. calongei (Moreno and Khalid 2009), the total figure is around 30 species.

Fungal taxonomic studies in Brazil have shown a rich gasteroid diversity (Baseia and Milanez 2002; Baseia et al. 2003; Baseia and Calonge 2005, 2006). To date, 12 Phallus species have been reported from Brazil, but 5 of these $[P$. callichrous (A. Möller) Lloyd, P. campanulatus Berk., P. granuloso-denticulatus Brown, P. subtilis (A. Möller) Lloyd and P. moelleri Lloyd] are doubtful species and 1 (P. impudicus L.: Pers.) may have been introduced by man.

Phallus glutinolens was originally described from Atlantic Forest of Santa Catarina (Möller 1895) and was rediscovered in 2007 in the same area. This new collection revealed that Möller's original description was based on 
young basidiomata and important morphological data about mature basidiomata are lacking. Therefore, the aim of this article is to present an emendation of $P$. glutinolens and to provide a detailed description with comments and illustrations of the species.

\section{Materials and methods}

Material collection was carried out during 2007 at the Hotel Plaza Caldas da Imperatriz Resort \& Spa, Santo Amaro da Imperatriz, in the state of Santa Catarina. This site contains 140 ha of preserved area, owing to its proximity to the Parque Estadual da Serra do Tabuleiro, a 90,000-ha remnant of Atlantic Forest.

Basidiomata were examined and photographed in the field. Colours were coded according to Kornerup and Wanscher (1978), with the letter "KW", bracketed in the text and simultaneously described. The specimens are kept at the UFRN and FLOR herbaria.

Macroscopic characters were described on fresh and dry material. Light macroscopic (LM) observations were done following the traditional methods used in mycology.

\section{Taxonomic description}

Phallus glutinolens (A. Möller) O. Kuntze emend. Trierveiler-Pereira, Calonge \& Baseia (Figs. 1, 2, 3, 4, 5, 6, 7 and 8)

三Ithyphallus glutinolens A. Möller, Bot. Mitt. Trop. 8: 100, 148 (1895)

Egg subglobose, 15-20 mm diam., brown (KW 4F4), with a whitish mycelial rhizomorph arising from the base. Mature basidioma $40-60 \mathrm{~mm}$ high, $50 \mathrm{~mm}$ in dry conditions. Receptacle cellular, globose when young and then campanulate with a perforate apex, $20 \mathrm{~mm}$ diam., covered by an olive-blackish gleba (KW 1F5), gelatinous, receptacle without gleba white, smooth. Pseudostipe cylindrical, spongy, with granular surface, whitish, 40$50 \times 10-15 \mathrm{~mm}$, attenuate at the apex; constituted by pseudoparenquimatic cells, $15-30 \times 17-28 \mu \mathrm{m}$. Ring frequently present in young specimens. Volva subglobose, 20-25 mm diam., duplex with superficial layer dark yellow (KW 4C8), formed by pseudoparenchymatous cells, $18-45 \times 15-40 \mu \mathrm{m}$; inner layer light yellow (KW 4A5), constituted by unbranched and septate threads, 4$5 \mu \mathrm{m}$ diam.; disciform base with a central rhizomorph 20 $30 \mathrm{~mm}$ long. Basidia not observed. Spores ellipsoid to cylindrical, 3.5-4.5 × 1.5-2 $\mu \mathrm{m}$, greenish, hyaline, smooth. When fresh, the specimens have an aromatic, sweet smell, which changes to tarlike when dry.
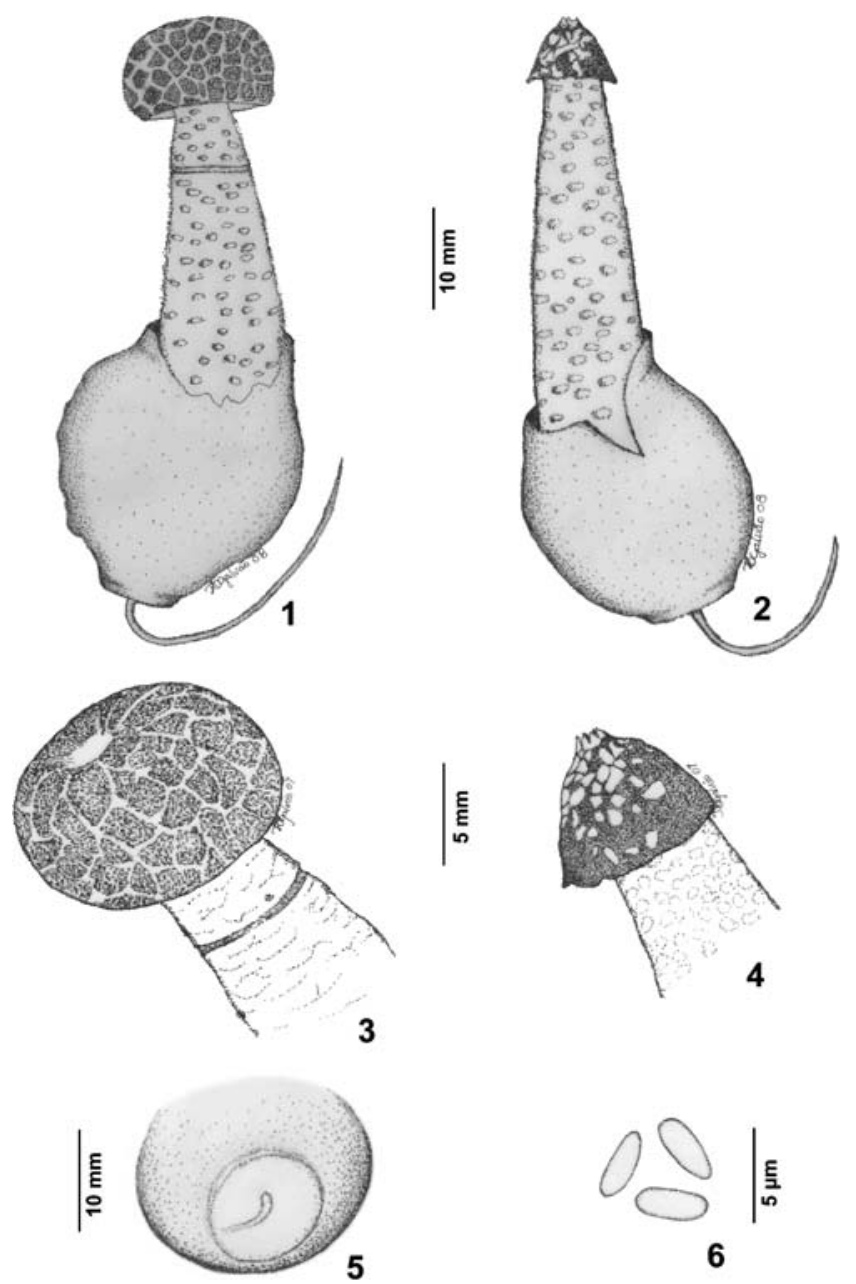

Fig. 1-6 1. Phallus glutinolens. Young basidiome 2. Phallus glutinolens. Mature basidiome 3. Phallus glutinolens. Receptacle of a young basidiome 4. Phallus glutinolens. Receptacle of a mature basidiome 5. Phallus glutinolens. Discoid plate at the base of the volva 6. Phallus glutinolens. Basidiospores

Voucher material: Brazil, Santa Catarina, Santo Amaro da Imperatriz, Hotel Plaza Caldas da Imperatiz Resort \& Spa, Pousada da Mata, Trilha da Estrada Velha, $450 \mathrm{~m}$ asl, growing in groups on soil, leg. L. Trierveiler-Pereira, Baltazar \& Maccarini, 12.V.2007 (UFRN 834, FLOR 77079).

\section{Discussion}

Macro- and microscopic features of the young specimens examined agree with Möller's original description (1895). Additional taxonomic features observed are: campanulate and perforate apex at maturity and disciform volva base. 


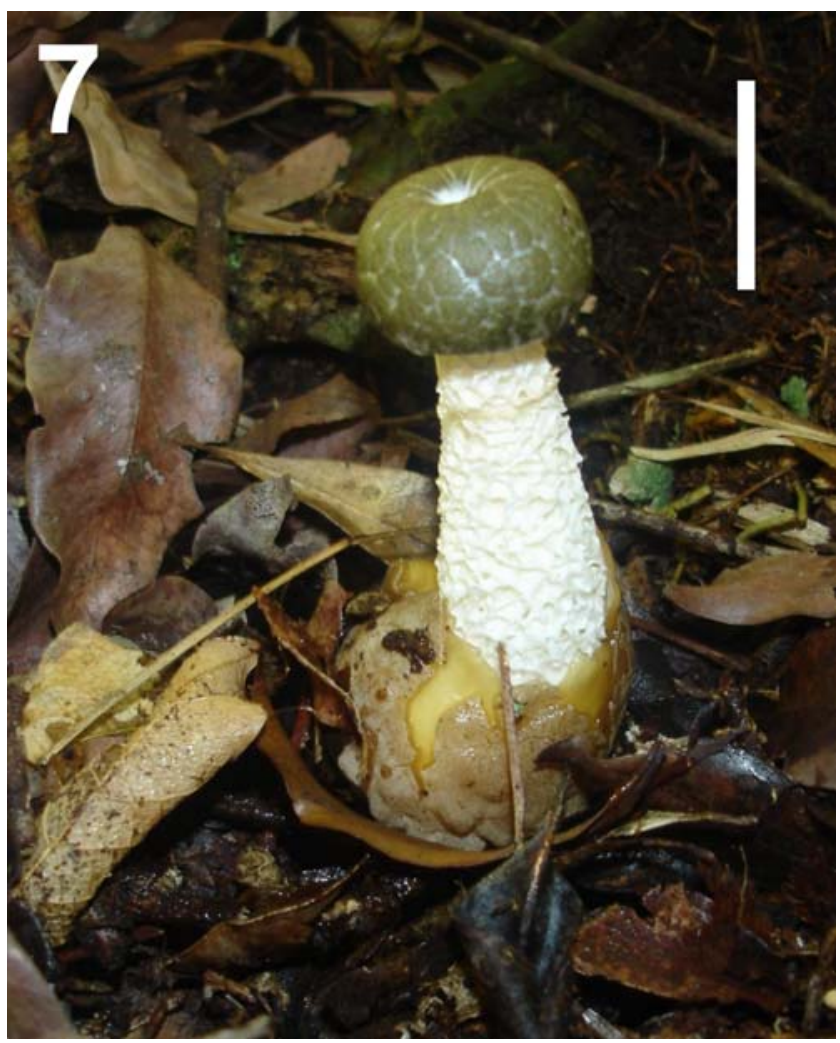

Fig. 7 Young basidiome of Phallus glutinolens (scale bar=10 mm), photo by L. Trierveiler-Pereira

Calonge (2005) described the receptacle of $P$. glutinolens as having a granulose surface, due to a misinterpretation of Möller's original description. A later translation of the original German text has showed that the receptacle was smooth, like the examined specimens here. The disciform volva base, another very important characteristic for defining this taxon, was not mentioned by Möller (1985) or Calonge (2005).

Wright (1960) noticed that Argentinean specimens of $P$. glutinolens had a campanulate receptacle and larger basidiospores $(5.1-6.9 \times 2-3.1 \mu \mathrm{m})$ and suggested that Möller's description may have been based on young basidiomata. However, the presence of such large basidiospores in the Argentinean material leads us to believe that the material is $P$. macrosporus Liu, Li \& Du (Liu et al.1980), whose spores are 7-7.6 $\times 4-4.7 \mu \mathrm{m}$, but in this case the volva is pink.

Two species relatively close to $P$. glutinolens share a number of morphological features: P. yunnanensis (M. Zang \& R.H. Pertersen) Kreisel, which also shows a discoid base in the pseudostipe but lacks a volva (Kreisel 1996), and $P$. ravenelli Berk. \& M.A. Curtis, which shows a white receptacle and pseudostipe, but a granulose receptacle surface (Berkeley 1873).
Key to Phallus species reported from Brazil (excluding doubtful species)

1 Receptacle surface wig-like after the gleba disappears, formed of lamellate plates, usually flattened on the top P. galericulatus

1 * Receptacle surface smooth, rugulose or reticulate, never flattened 2

2 Basidioma very small, up to $1.5 \mathrm{~cm}$ high; growing on wood P. pygmaeus

2* Basidioma larger; growing on soil 3

3 Pseudostipe reddish, orange to pinkish P. rubicundus 3* Pseudostipe not pigmented 4

4 Receptacle globose to hemispherical when young; volva with a discoid plate at base P. glutinolens

4* Receptacle campanulate; volva without a discoid plate at base 5

5 Basidioma without indusium or with a rudimentary one P. impudicus

$5^{*}$ Basidioma with a well-developed indusium 6

6 Receptacle surface reticulate $P$. indusiatus

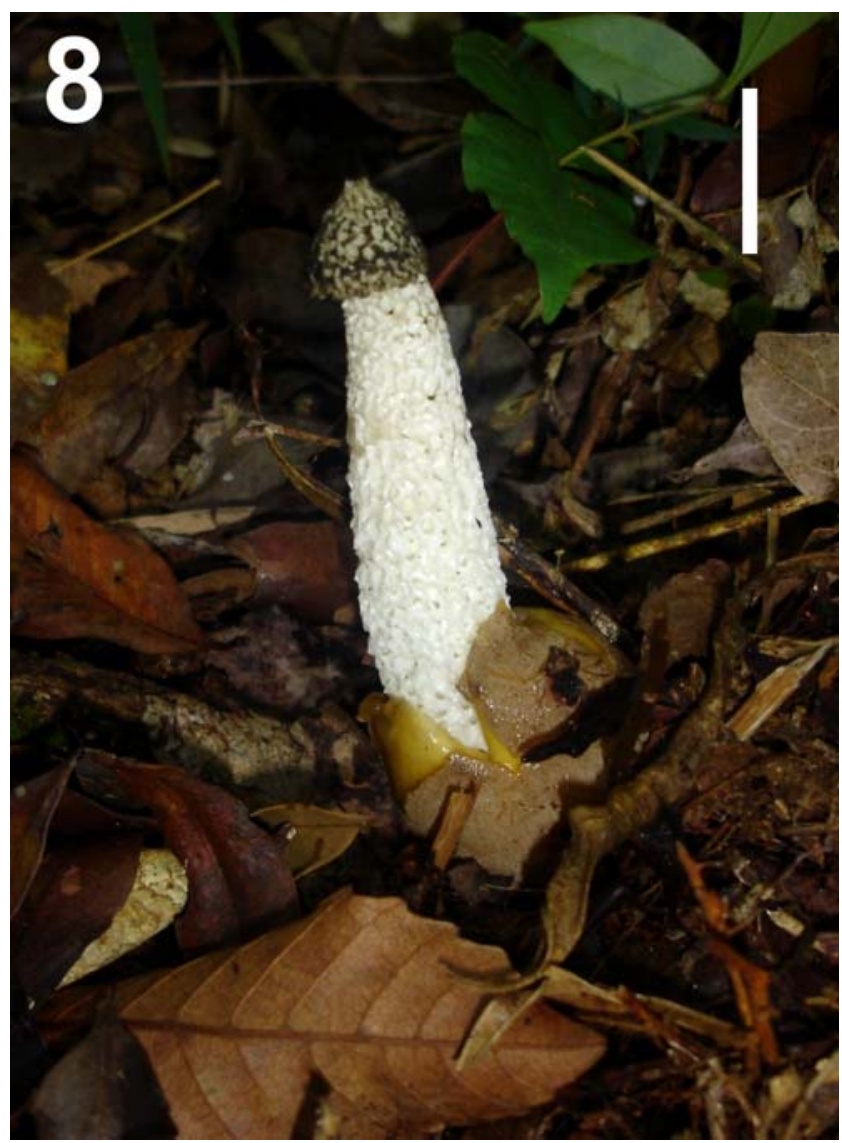

Fig. 8 Mature basidiome of Phallus glutinolens (scale bar=10 mm), photo by L. Trierveiler-Pereira 
6* Receptacle surface granulose to rugulose $P$. merulinus

Acknowledgements We are grateful to Hotel Plaza Caldas da Imperatriz Resort \& Spa for providing a scholarship to Larissa Trierveiler Pereira and to the Hotel's biologist, Fernando Maciel Brüggemann, for his support. We also thank Tereza Cristina de Oliveira Galvão for her illustrations and Ramón Morales for translating Möller's original description. This study was partially financed by the Conselho National de Desenvolvimento Cientifico e Tecnológico (CNPq).

\section{References}

Baseia IG, Milanez AI (2002) Geastrum setiferum (Gasteromycetes): a new species with a setose endoperidium. Mycotaxon 84:135139

Baseia IG, Calonge FD (2005) Aseroë floriformis: a new phalloid with a sunflower-shaped receptacle. Mycotaxon 92:169-172

Baseia IG, Calonge FD (2006) Geastrum hirsutum: a new earthstar fungus with a hairy exoperidium. Mycotaxon 95:301-304

Baseia IG, Gibertoni TB, Maia LC (2003) Phallus pygmaeus, a new minute species from a Brazilian tropical rainforest. Mycotaxon 85:77-79

Berkeley MJ (1873) Notices of North American fungi (cont. from p. 20). Grevillea 2(15):33-35

Calonge FD (2005) A tentative key to identify the species of Phallus. Bol Soc Micologica Madr 29:9-18

Calonge FD, Kreisel H (2002) Phallus minusculus sp. nova from tropical Africa. Feddes Repert 113:600-602. doi:10.1002/ fedr.200290007
Calonge FD, Menezes de Sequeira M, Freitas T, Rocha E, Franquinho L (2008) Phallus maderensis sp. nov., found in Madeira, Portugal. Bol Soc Micol Madr 32:101-104

Dring DM, Rose AC (1976) Additions to West African phalloid fungi. Kew Bull 31:741-751. doi:10.2307/4119427

Fidalgo F (1968) Introdução a história da micologia brasileira. Rickia $3: 1-44$

Friederichsen I (1977) Das Schicksal der von A. Möller in Brasilien (1890-1895) gesammelten Pilze sowie eine Liste der noch vorhandenen Sammlungsstücke. Mitt Staatsinst Allg Bot Hamburg 15:99-104

Hiepko P (1987) The collections of the Botanical Museum BerlinDahlem (B) and their history. Englera 7:219-252

Hosaka K, Bates ST, Beever RE, Castellano MA, Dominguez L, Nourha ER, Giachini AJ, Kenney SR, Simson NB, Spatafora JW, Trappe JM (2006) Molecular phylogenetics of the gomphoidphalloid fungi with an establishment of the new subclass Phallomycetidae and two new orders. Mycologia 98:949-959. doi:10.3852/mycologia.98.6.949

Kasuya T (2008) Phallus luteus comb. nov., a new taxonomic treatment of a tropical Phalloid fungus. Mycotaxon 106:7-13

Kornerup A, Wanscher JH (1978) Methuen Handbook of Colours, 3rd edn. Eyre Methuen, London

Kreisel H (1996) A preliminary survey of the genus Phallus sensu lato. Czech Mycol 48:273-281

Li TH, Liu B, Song B, Deng WQ, Zhou TX (2005) A new species of Phallus from China and P. formosanus, new to the mainland. Mycotaxon 91:309-314

Möller A (1895) Brasilische Pilzblumen. Gustav Fischer, Jena, Germany

Moreno G, Khalid AN (2009) A new species of Phallus from Pakistan. Mycotaxon 107 (in press)

Wright JE (1960) Faloideas Sud y Centroamericanas. Lilloa 30:339359 